\title{
Liver X Receptors and Male (In)fertility
}

\author{
Sheba Jarvis ${ }^{1, *}$, Catherine Williamson ${ }^{2}$ and Charlotte L Bevan ${ }^{1}[\mathbb{C}$ \\ 1 Department of Surgery and Cancer, Imperial College London, London W12 0NN, UK; \\ charlotte.bevan@imperial.ac.uk \\ 2 Department of Women and Children's Health, King's College London, London SE1 9UL, UK; \\ catherine.williamson@kcl.ac.uk \\ * Correspondence: sheba.jarvis@imperial.ac.uk
}

Received: 3 October 2019; Accepted: 23 October 2019; Published: 29 October 2019

\begin{abstract}
Liver X receptors (LXRs) are ligand-dependent transcription factors acting as 'cholesterol sensors' to regulate lipid homeostasis in cells. The two isoforms, LXR $\alpha$ (NR1H3) and LXR $\beta$ (NR1H2), are differentially expressed, with the former expressed predominantly in metabolically active tissues and the latter more ubiquitously. Both are activated by oxidised cholesterol metabolites, endogenously produced oxysterols. LXRs have important roles in lipid metabolism and inflammation, plus a number of newly emerging roles. They are implicated in regulating lipid balance in normal male reproductive function and may provide a link between male infertility and lipid disorders and/or obesity. Studies from Lxr knockout mouse models provide compelling evidence to support this. More recently published data suggest distinct and overlapping roles of the LXR isoforms in the testis and recent evidence of a role for LXRs in human male fertility. This review summarises the current literature and explores the likely link between LXR, lipid metabolism and male fertility as part of a special issue on Liver $\mathrm{X}$ receptors in International Journal of Molecular Sciences.
\end{abstract}

Keywords: liver X receptors; testis; infertility; steroidogenesis; oxysterols

\section{Introduction}

Liver X receptors (LXRs) are transcription factors that act as master regulators of lipid homeostasis by functioning as 'cholesterol sensors' [1]. They are part of the nuclear receptor (NR) superfamily with two isoforms, $\mathrm{LXR} \alpha(\mathrm{NR} 1 \mathrm{H} 3)$ and $\mathrm{LXR} \beta$ (NR1H2), encoded by distinct genes located on chromosome 11 and 19 , respectively $[2,3]$.

LXRs are ligand activated and upon activation form permissive heterodimers with Retinoid X receptors (RXRs) [4]. They also have an important relationship with another nuclear receptor, Farnesoid $X$ receptor (FXR), and together they play important roles in cholesterol-bile acid homeostasis [4].

There is an increasing interest in the roles of LXRs outside the enterohepatic system, where they were initially characterised, with evidence for regulatory effects in macrophages, brain, adipose cardiorespiratory and endocrine systems. These emerging roles are in cancer, autoimmune and neurodegenerative diseases as well as inflammation $[5,6]$. It is also increasingly apparent that LXRs are critical to male reproduction and this article focuses on their roles in the testis and epididymis, sites of spermatogenesis and post-testicular maturation, respectively.

\section{LXR Structure, Function and Expression}

LXRs are referred to as a Class II nuclear receptors since they are located in the nucleus where, regardless of ligand binding, they bind LXR response elements (LXREs) in the promotor region of their target genes and recruit corepressors, causing repression of target gene expression. LXR co-repressors include silencing mediator of retinoic acid and thyroid receptor (SMRT) and nuclear 
receptor corepressor (NCoR) $[7,8]$. Upon ligand binding, conformational change in the protein leads to a shift to coactivator recruitment and target gene expression.

LXR $\alpha$ and LXR $\beta$ share $~ 77 \%$ amino acid sequence homology in the ligand binding domain [9] and each have 4 functional domains. These are (i) an $\mathrm{N}^{\prime}$ terminal domain, containing coactivator binding sites and a transcriptional function (AF-1) (ii) the DNA-binding domain, a highly conserved area with the binding activity mediated by two zinc fingers, (iii) a hinge region allowing receptor flexibility and corepressor recruitment and (iv) a $\mathrm{C}^{\prime}$ terminal region with the AF-2 domain which regulates transcription via interactions with co-activators and co-repressors after ligand binding. The ligand binding domain contains $\alpha$ helices organised around a central ligand binding hydrophobic pocket $[10,11]$. The LXREs, bound by LXR/RXR heterodimers, are referred to as DR-4 binding sites and are usually comprised of a repeated sequence of 5-AGGTCA-3 separated by a 4 nucleotide spacer [2,12]. Although this is a common LXRE, recently other LXR binding sites have been identified from ChIP-seq studies [12-14].

Interestingly, other modulatory roles for LXRs are increasingly described as involving post-translational modification processes including SUMOylation, acetylation, phosphorylation, ubiquitination and O-GlcNacylation, but there is a paucity of data in these areas and in particular with regards to the potential for non-genomic effects of LXRs [5,15].

In terms of pattern of expression, LXR $\beta$ is ubiquitously expressed throughout the body, whereas $\mathrm{LXR} \alpha(\mathrm{NR} 1 \mathrm{H} 3)$ is most highly expressed in metabolically active tissues such as the liver, kidney, adrenal glands, macrophages and the intestine [16]. In the testis, there is widespread expression of LXRs with differential expression in the various germ and somatic cell types $[17,18]$ whilst the cells of the epididymis express both LXR isoforms.

\section{LXRs Are Activated by Oxysterols and Are Central Regulators for Lipid Metabolism}

Oxysterols are oxidised cholesterol metabolites which act as natural ligands for LXR receptors; they have a side chain hydroxyl group which is essential for LXR activation [19]. Oxysterols that bind to and activate LXR, with varying affinity and potency, respectively, include: 20(S)-, 22(R)-, 24(S)-, 25-, (25R),26-hydroxycholesterol; 24(S),25-epoxycholesterol, cholestenoic acid as well as the cholesterol intermediates: desmosterol, follicular fluid meiosis-activating sterol (FF-MAS), testis meiosis-activating sterol (T-MAS) [3,20-22]. Many of the LXR activating oxysterols are present in the reproductive tract [23-25]; however, there is still a limited amount of information on the role of oxysterols, with tissue specific and potentially cell specific variation in oxysterol production, making it problematic to predict which are the most physiologically relevant. This, plus the varying potency of endogenous ligands and their potential to activate other nuclear receptors [11,26], is likely the reason that often under experimental conditions, synthetic LXR ligands - notably T0901317 and GW3965 - are used. Again, however, although these are relatively specific for LXR, data should be interpreted with the caveat that they may vary in affinities for LXR isoforms and potentially different effects to endogenous oxysterols.

In the female, FF-MAS (produced from lanosterol and catalysed by lanosterol $14 \alpha$-demethylase protein complex) has been shown to be important for oocyte meiosis and survival and is associated with successful implantation [27-29]. FF-MAS has been shown to stimulate a putative receptor within oocytes, for which LXR $\alpha$ may be a candidate [30,31]. FF-MAS is synthesized in large amounts by granulosa cells of the maturing ovarian follicle but whether similar findings are seen in the male counterpart, the Sertoli cell of the testis, requires more investigation. However, T-MAS (converted from FF-MAS by sterol $14 \alpha$-reductase) has been identified in the bull and mouse testis and is potentially important for meiosis [32-34]. Furthermore, lanosterol $14 \alpha$-demethylase, important in oxysterol production, shows stage-specific expression in developing spermatids [34]. Also, 25-hydroxycholesterol is able to activate the LXR receptors and is produced by rat testicular macrophages and used by Leydig cells in androgen production $[35,36]$. More recently this oxysterol and (25R),26-hydroxycholesterol (previously denominated 27-hydroxycholesterol) were identified in 
human sperm, with 25-hydroxycholesterol observed to mediate the acrosome reaction necessary for normal sperm physiology and fertilization [22,25].

Cholesterol homeostasis is strictly regulated within cells, and the main source of cholesterol is dietary with cholesterol uptake into cells via scavenger receptor, class B type (SR-B1) with SR-B1 overexpression states associated with high cellular esterified cholesterol levels [37] or due to de novo cholesterol biosynthesis [38]. The cholesterol biosynthesis pathways require acetyl CoA, and a series of enzymatic reactions occur during sterol metabolism which, via mevalonate, culminate in cholesterol production.

Maintenance of cellular and systemic sterol levels is an essential homeostatic process, and LXRs act as critical sterol sensors but also regulate fatty acid and phospholipid metabolism [39]. One method of cholesterol elimination in the liver is by induction of CYP7A1; this encodes the enzyme cholesterol $7 \alpha$-hydroxylase which catabolises cholesterol into bile acids for excretion via the LXR-upregulated ATP binding cassette (ABC) transporters: ABCG5 and ABCG8 [40,41]. Another means of tightly regulating cellular cholesterol levels is reverse cholesterol transport (RCT), whereby excess cholesterol is effluxed from peripheral tissues and returned to the liver via high-density lipoproteins (HDL). LXRs regulate cellular cholesterol efflux transporters important for RCT, ABCA1 and ABCG1 [42,43]. ABCA1 controls transfer of cholesterol and phospholipids from plasma membranes to pre-HDL or to lipid-poor APOA-1 molecules [44] and is assisted by ABCG1 [45] (Figure 1).

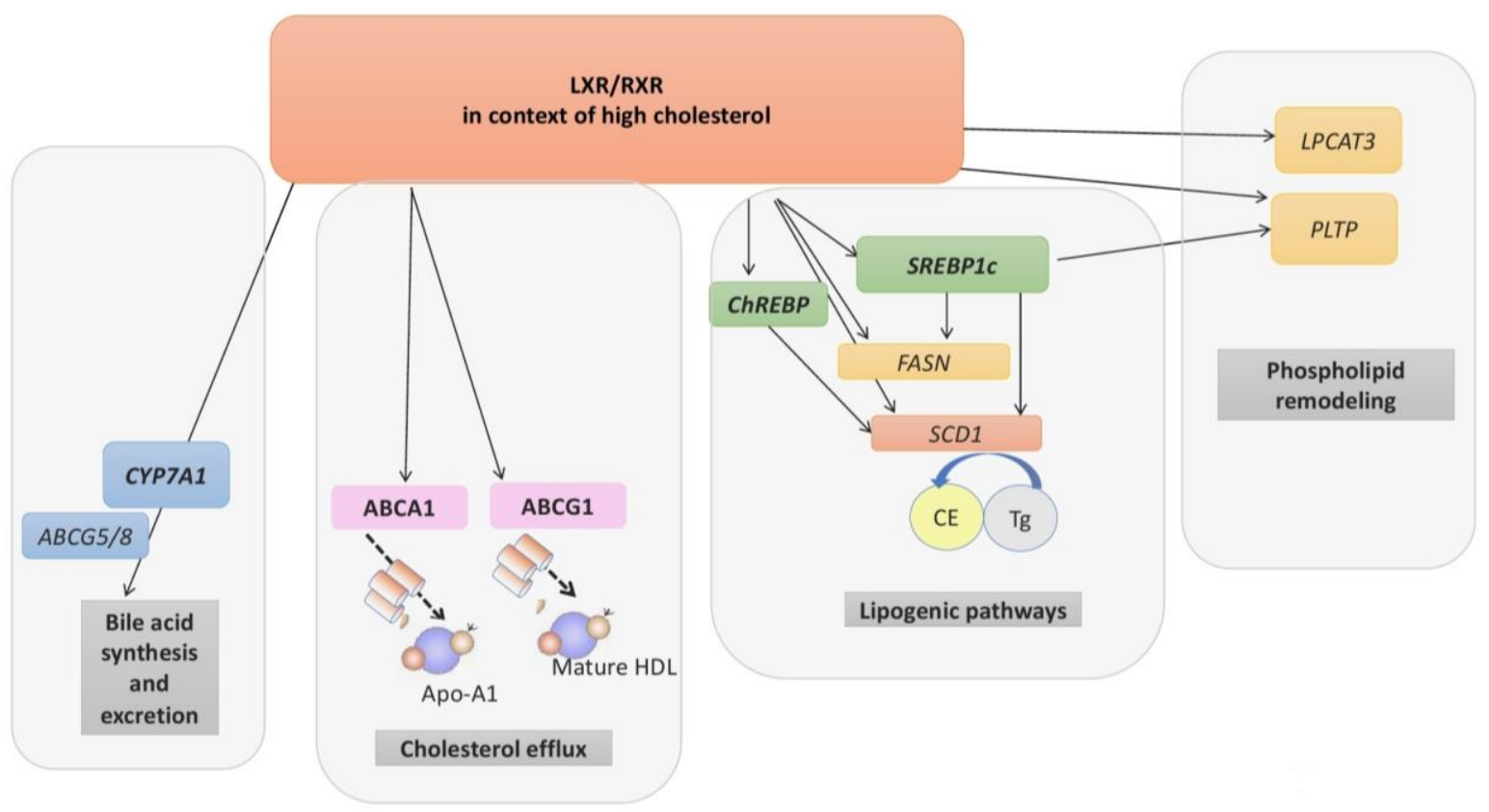

Figure 1. The roles of LXRs in lipid metabolism. LXRs regulate hepatic cholesterol elimination by upregulating CYP7A1 as well as excreting cholesterol via ATP binding cassette transporters ABCG5/8 (typically in hepatobiliary system). They also facilitate reverse cholesterol transport by regulating cholesterol efflux from peripheral tissues and cells (e.g., typically macrophages, Sertoli cells of the testis) where ABCA1 and ABCG1 transport cholesterol to APO-A1-HDL and mature HDL respectively. LXRs regulate lipogenesis (usually via hepatic LXR $\alpha$ ) with upregulation of SREBP1c, FASN and SCD-1. ChREBP is also able to activate SCD- 1 but has a role in carbohydrate metabolism. Finally, LXRs regulate phospholipid remodelling through direct activation of LPCAT3, a crucial enzyme in this process which facilitates the turnover of PUFAs (shown to occur in macrophages, liver, intestine), which will affect membrane phospholipid and allows cells to become resistant to sterol mediated cellular stress. LXRs and the SREBP1 axis are also important for the activation of PLTP which facilitates the production of nascent VLDL. CE, cholesteryl esters; Tgs, triglycerides. 
LXRs also control de novo lipogenesis via induction of sterol regulatory element binding protein 1c (SREBP1c), a major gatekeeper of lipogenesis. The SREBP family has 3 members, which are part of a family of basic helix-loop-helix leucine zipper transcription factors that regulate key lipogenic genes, including fatty acid synthase (FASN) and stearoyl coenzyme A desaturase 1 (SCD1); these are also directly targeted by LXR $\alpha$ and LXR $\beta$. Carbohydrate metabolism is also implicated; LXR targets carbohydrate response element binding protein (ChREBP) and is another example of how LXRs influence lipogenesis $[39,46]$ (Figure 1).

LXRs are also involved in phospholipid remodelling processes and $\mathrm{LXR} \alpha$ induces expression of the gene encoding the enzyme lysophosphatidylcholine acyltransferase 3 (LPCAT3), involved in phospholipid remodelling in response to changing sterol levels [47,48]. LPCAT3 catalyses incorporation of polyunsaturated fatty acids at the $s n-2$ site of lysophospholipids, which affects the fluidity and the curvature of the membranes and protects against high sterol related stress at cell membranes [39]. Phospholipid transfer protein (PLTP) is also a direct LXR target, which transfers phospholipids between lipoprotein particles $[39,49,50]$. Together, LXR and SREBP1c activate PLTP which produces nascent VLDL (very low density lipoprotein) particles [51] (Figure 1).

The roles of LXRs in cholesterol homeostasis were revealed largely by use of the transgenic LXR knockout mice. Lxr $-/$ - mice fed a high fat diet develop hepatic steatosis, from deposition of cholesteryl esters due to failure to upregulate hepatic Cyp7a1, which would normally lead to conversion of cholesterol into bile acids [40,52]. More recently, a liver specific knockout revealed that hepatic LXR $\alpha$ modulates lipoprotein particle number and intestinal LXR activity is likely responsible for increasing HDL cholesterol [53].

\section{Cholesterol, Somatic Cells and Germ Cell Maturation}

Spermatogenesis is a complex but highly ordered process of male germ cell maturation taking place within the seminiferous tubules [54]. Once produced, spermatozoa exit the seminiferous tubules and transit through the epididymis, an accessory organ crucial for post testicular maturation. To function normally, the testis requires an orchestration of events which include germ cell proliferation, differentiation, apoptosis and critically communication between germ cell and somatic cell. This takes place between germ cells and Sertoli cells, as well as complex paracrine signalling between the somatic cells of the testis [55].

In the testis, cholesterol serves as a vital fuel for androgen production (during steroidogenesis), as well as in the maintenance of cell membranes and, along with fatty acids, is a potential energy source for Sertoli cells [56-58]. For germ cells, cholesterol is an important for membrane remodeling during spermatogenesis, and spermatocytes are capable of undergoing de novo lipogenesis and cholesterol uptake with a surge of cholesterol utilisation during meiosis [59]; it is not clear if this also occurs in other germ cell subtypes.

Cholesterol is the most abundant sterol in germ cell membranes, which undergo extensive remodelling during germ cell maturation in the testis and also in the epididymis. The ratios of different lipids within the spermatozoal membrane are important for normal functioning and subsequent signalling events and they are rich in polyunsaturated fatty acids (PUFAs), necessary for motility, capacitation and sperm-egg fusion $[60,61]$.

Sertoli cells are the 'nurse' cells for developing germ cells and their numbers are critical for spermatogenesis [62]. They are responsible for maintenance of the blood testis barrier (BTB), producing extracellular matrix, transport proteins, cytokines, androgen binding proteins (ABP) with many other functions including lipid storage and efflux [38]. Sertoli cells supply cholesterol and fatty acids needed for germ cell maturation $[56,57]$ and although they can undergo de novo lipogenesis this is not sufficient for the amount of lipid required for spermatogenesis [38]. Thus, uptake of circulating cholesterol into Sertoli cells via SR-B1 allows HDL-derived cholesteryl esters to be used as a major lipid source [63] and they may also use lipid droplets in this respect. 
Despite the need for large amounts of lipid, Sertoli cells must also have mechanisms whereby intracellular lipid levels can be finely tuned and they express high levels of jjABCA1 and ABCG1, key players in lipid efflux [64]. Any imbalance in lipid homeostasis may culminate in excessive lipid droplet (LD) deposition within the Sertoli cell cytoplasm, which can affect function. Excessive large LDs may cause mechanical dysfunction through altering cytoskeleton, and BTB disruption, affecting germ cell survival and maturation during spermatogenesis $[65,66]$.

Leydig cells also utilise large amounts of cholesterol for androgen production; regulation of steroidogenesis in these cells is highly complex and requires multiple enzymatic reactions. Although the Leydig cells can synthesise cholesterol de novo in the endoplasmic reticulum, this is not sufficient for steroidogenesis and other sources are required; these include utilisation of lipid droplets (LDs) of cholesterol esters and uptake of circulating lipoproteins, e.g., HDL via SR-B1and also uptake of low density lipoprotein [67]. LXRs (as well as other nuclear receptors including FXR, small heterodimer partner (SHP) and steroidogenic factor 1 (SF-1) have been implicated in the regulation of steroidogenesis [38,68].

When considering the post testicular maturation of sperm, marked changes in lipid composition are crucial for fertility. The passage of sperm through the epididymis is a crucial form of quality control of eradicating abnormal sperm but also facilitating modifications to the sperm membrane by altering the cholesterol content [34]. Cholesterol has a major effect on sperm membrane fluidity and cholesterol efflux is required for sperm to acquire appropriate characteristics necessary for capacitation. Therefore, any abnormality in cholesterol metabolism or phospholipid regulation could potentially impact male fertility $[38,69]$. Higher dietary cholesterol intake modifies spermatozoa quality in a negative manner in rodent studies [70] although more recently in human studies of seminal plasma, analysis suggests higher serum cholesterol levels are associated with favourable semen parameters [71,72]. Ultimately, a delicate balance, which is tightly regulated in the testis, is likely to be important.

\section{LXRs Are Important for Maintenance of Male Fertility}

LXR $\alpha$ and LXR $\beta$ are expressed in the mouse and human testes $[17,73,74]$ and an understanding of testicular LXRs has originated from studies using knockout mice where either LXR isoform (Lxr $-/$ - or Lxr $\beta-/-)$ or both LXR isoforms ( $\operatorname{xx} \alpha \beta \beta-/-)$ are ablated $[38,68]$. In the mouse, Leydig cells express mainly $\mathrm{LXR} \alpha$, and Sertoli cells express $\mathrm{LXR} \beta$, whilst both isoforms are expressed in germ cells [18]. Early work suggested redundancy of LXR isoforms since $L x r \alpha-/-$ or $L x r \beta-/$ - mice are fertile whilst in contrast, $L x r \alpha \beta-/-$ mice have a severe infertility phenotype $[18,66,73]$. Lxr $\alpha \beta-/-$ male mice are sub-fertile by $4-5$ months of age, confirmed by a markedly reduced pregnancy rate and decreased number of pups per litter, and rapidly progress to sterility by 10 months of age [18].

Histologically, many premature age-related testicular defects occur in the $L x r \alpha \beta-/$ - mice and the histological features relate to deranged lipid metabolism with lipid droplets within Sertoli cells of 3.5 month old male $L x r \alpha \beta-/$ - mice [18]. By 5.5 months more lipid droplets form in Sertoli cells and also in spermatids and $\sim 20-30 \%$ of the seminiferous tubules have cell aggregates with no spermatozoa. By 10 months of age there are mostly empty seminiferous tubules and by 12 months, marked cellular necrosis, larger size lipid droplets and completely disorganised seminiferous tubules are observed [18]. Additionally, basal expression of LXR-regulated genes such as Srebf1c, Fasn is decreased by around $40 \%$ although no changes are seen in $S r b 1, S c d 1$ or $A b c a 1$ expression [18].

Both of the single LXR knockouts are fertile, but a detailed assessment revealed that $L x r \beta-/-$ mice have lipid droplets within the Sertoli cells from 2.5 months of age, and $L x r \alpha-/$ - mice have lower levels of intratesticular testosterone and reduced expression of the gene encoding $3 \beta$-Hydroxysteroid dehydrogenase $(3 \beta-H S D)$, important for androgen production $[18,66]$. Treatment with the LXR $\alpha$ and LXR $\beta$ agonist T0901317 restored testosterone levels with increased expression of steroidogenic acute regulatory protein (StAR) enzymes $[18,66]$.

An important recently published study of an additive transgenesis model using $\operatorname{Lxr} \alpha \beta-/$ - mice in which LXR $\beta$ was reinstated only in Sertoli cells (driven by the Anti-Mullerian hormone promoter) 
$(\operatorname{Lxr} \alpha \beta-/-: A M H-L x r \beta)$ has provided further interesting information. This 'rescued' strain has a reduction in lipid droplets, increased integrity of the BTB and normalisation of testosterone. Thus, information gained from these LXR mouse models has provided new information on the likely roles of LXRs in the testis (summarised Table 1). In human fertility, LXRs are likely to have a similar role to those in the mouse and may be related to premature loss of fertility. Both $L X R \alpha$ and $L X R \beta$ are expressed in human testicular biopsy specimens along with low levels of SREBP1c and IDOL, both of which are LXR target genes described in men with worse fertility phenotype [74]. However, to date, the specific role of each LXR isoform in the human testis has not yet been elucidated.

Table 1. Summary of defects reported in LXR knockout mice $[18,73]$ and effects of rescuing $\operatorname{Lxr} \beta$ in Sertoli cells [66].

\begin{tabular}{|c|c|c|c|}
\hline Genotype & Fertile & & Abnormalities/Comments \\
\hline$L x r \alpha-/-$ & yes & \multicolumn{2}{|c|}{$\begin{array}{ll}\text { - } & \text { Low testosterone levels } \\
\text { - } & \text { Normal germ cell numbers }\end{array}$} \\
\hline$L x r \beta-/-$ & yes & \multicolumn{2}{|c|}{$\begin{array}{l}\text { - } \quad \text { Sertoli cells: cholesterol deposition } \\
\text { - } \quad \text { Normal germ cell numbers }\end{array}$} \\
\hline $\operatorname{Lxr} \alpha \beta-/-$ & $\begin{array}{l}5 \text { months of age } \\
\text { then infertile }\end{array}$ & $\begin{array}{l}3.5 \text { months } \\
5.5 \text { months }\end{array}$ & $\begin{array}{ll}\text { - } & \text { Lipid droplets in Sertoli cells } \\
\text { - } & \text { Larger Leydig cells } \\
\text { - } & \text { 20-30\% abnormal seminiferous tubules } \\
\text { - } & \text { Cell aggregates not spermatozoa } \\
\text { - } & \text { Empty tubules } \\
\text { - } & \text { Lipid droplets }++ \text { in Sertoli cells } \\
\text { - } & \text { Completely disorganized testis, } \\
\text { - } & \text { Numerosterol deposition } \\
& \text { seminiferous vacuoles in interstitial and } \\
\end{array}$ \\
\hline
\end{tabular}

\begin{tabular}{|c|c|c|}
\hline $\begin{array}{l}\text { Lxr } \alpha \beta \text {-/- with } \\
\text { rescue } \operatorname{Lxr} \beta \\
\quad \text { :AMH }\end{array}$ & Unknown & 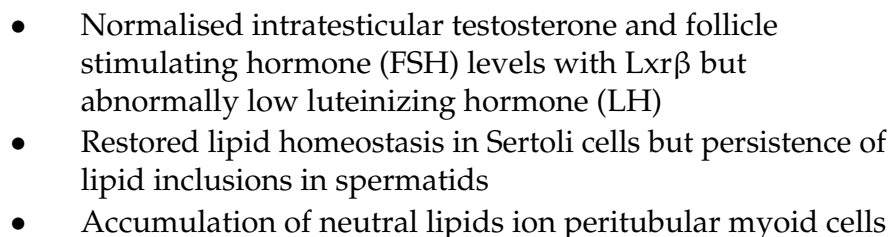 \\
\hline
\end{tabular}

\section{LXR $\alpha$ and LXR $\beta$ Control Germ Cell Numbers with Distinct and Overlapping Roles in Both Germ and Somatic Cells of the Testis}

Spermatogenesis is tightly regulated process and is hormonally regulated by the hypothalamic-pituitary-gonadal (HPG) axis, with pulsatile secretion of gonadotropins (LH and FSH) leading to androgen synthesis by Leydig cells. Sertoli cell numbers and function dictate germ cell number, with a delicate balance between germ cell proliferation and apoptosis [55]. Successful spermatogenesis requires intact germ:somatic cell and somatic:somatic cell relationships within the testis.

In $\operatorname{Lx} \alpha \beta$-/- mice there is increased loss of germ cells by apoptosis and reduced proliferation activity, leading to premature sterility $[18,73]$. The mechanisms by which this occurs are elusive but interestingly there is compensation between the LXR isoforms. It has been shown that $L x \mathrm{r} \alpha-/$ - mice have a significantly higher number of apoptotic cells compared with wild-type mice but this is not the case in the $\operatorname{Lxr} \beta-/$ - mice $[18,66]$. Interestingly, $\operatorname{Lxr} \beta-/-$ mice exhibit reduced germ cell proliferation which would ordinarily lead to reduced germ cell numbers; however, a compensatory reduction in 
apoptosis genes ensures little effect on germ cell numbers [18,66]. Ultimately, the marked germ cell loss observed in the $L x r \alpha \beta-/$ - mice is likely multifactorial with some direct effect on germ cells. However, with over 40 germ and somatic cell subtypes expressing either LXR $\alpha$ or LXR $\beta$ in the adult testis, delineating germ cell expression pattern, deciphering the stages and gauging how LXR may mediate any direct effects on germ cells remains a challenge.

Deregulation of Sertoli cells alone in LXR knockout mice may contribute to germ cell loss, as Sertoli cells are so crucial for all aspects of germ cell development in producing nutrients, growth factors and lipids. Furthermore, their role in maintenance of the BTB, keeping germ cells protected in an immune privileged site, is a crucial one. In $L x r \beta-/-$ and $L x r \alpha \beta-/-$ mice, Sertoli cells become lipid laden and it can be postulated the large lipid droplets in the adluminal compartment of the testis mechanically disrupt the cytoskeleton, impacting the BTB and culminating in vulnerability of meiotic germ cells and loss of the germ cell pool. Additionally, it is well recognised that Sertoli cell function is important for germ cell lipid homeostasis, but the additive transgenesis model referenced above has shown new insights around this [66]. In this model, where LXR $\beta$ is reinstated into Sertoli cells ( $L x r \alpha \beta$ -/-:AMH-Lxr $\beta)$, there is an increase in $A b c a 1, A b c g 1$ with normalisation of intracellular cholesterol levels in the testis. However, a persistence of lipid inclusions in spermatids suggests that, in these cells, regulation of lipids may be independent of the LXR $\beta$ activity in Sertoli cells [66].

Other somatic cells, such as Leydig, cells are important for germ cell function and numbers, and the low testosterone described in both the $L x r \alpha-/$ - and $L x r \alpha \beta-/$ - mice will affect germ cell development since adequate testosterone and functioning androgen receptor are required for spermatogenesis maintenance $[75,76]$. Furthermore LXRs regulate inhibin and FSH levels, and low FSH levels are observed in $L x r \alpha \beta$-/- mice which may influence spermatogonial number, entry into meiosis, and have indirect effect on androgen production on Leydig cells [77].

\section{LXR $\alpha$ Regulates Testosterone Production but Requires Cooperation from LXR $\beta$-Expressing Sertoli Cells}

Androgens are mainly produced by the Leydig cells of the testis and it is recognised that the LXR agonist T0901317 induces a 13-fold increase in intratesticular testosterone [18]. Studies using Lxr $\alpha-/$ mice revealed diminished steroidogenic activity of Leydig cells and low testosterone levels. Central endocrine function was also affected, with reduced mRNA expression of the $\beta$ chain of the luteinizing hormone $(L h)$ receptor in the pituitary and decreased follicle stimulating hormone (FSH) in both $L x r \alpha$ -/- and $L x r \alpha \beta$-/- mice [18]. In the $L x r \alpha \beta$-/-:AMH- $\operatorname{xrr} \beta$ transgenic mouse model, normalisation of intratesticular testosterone and genes encoding steroidogenic enzymes Star and $3 \beta-h s d 1$ and partial restoration of FSH occur [66]. Thus, restoration of LXR $\beta$ in Sertoli cells normalised steroidogenesis in Leydig cells independent of the hypothalamus or pituitary gland (Figure 2). This suggested a paracrine interaction between Sertoli and Leydig cells driven by LXR $\beta$ that restores androgen levels, highlighting the cooperation between Sertoli and Leydig cell in terms of endocrine function [66].

However, there are persistently low LH levels in these mice, suggesting a remaining central defect in LH secretion not rescued by reintroduction of $\operatorname{Lxr} \beta$ into Sertoli cells. The hypothalamus also expresses both $L x r \alpha$ and $L x r \beta$, and pharmacological LXR activation with GW3965 leads to GnRH and gonadotrophin responses [78,79].

Together, this all suggests that LXRs are important for androgen synthesis and the low testosterone levels observed in $L x r \alpha \beta-/-$ mice [18] may be due to effects at multiple levels of the HPG axis, but normalisation of androgens can occur if LXR $\beta$ is reintroduced in Sertoli cells [66]. 


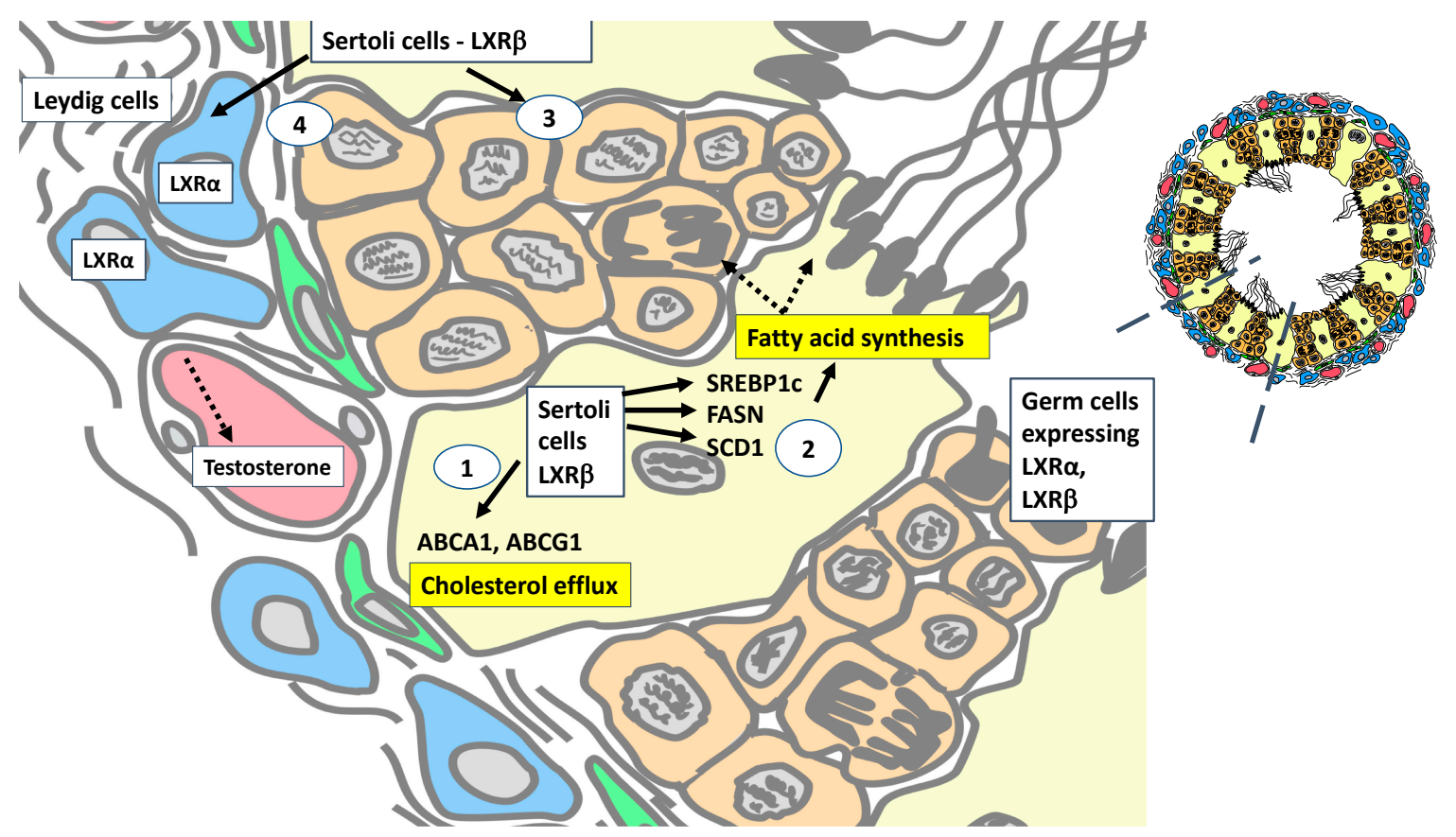

Figure 2. Schematic representation of seminiferous tubule and interstitium illustrating main roles of LXRs in the testis. LXR $\alpha$ is expressed in Leydig cells and LXR $\beta$ is expressed in Sertoli cells. Male germ cells express both isoforms. LXR $\beta$ regulates expression of genes important for lipid homeostasis processes such as (1) cholesterol efflux notably ABC transporters ABCA1, ABCG1 which reduce cellular cholesterol levels (2) fatty acid synthesis genes SREBP1c, SCD1, FASN and fatty acids. which are used by Sertoli cells but also maturing germ cells as fuel (3) LXR $\beta$ is important for maintenance of the blood testis barrier and (4) LXR $\beta$ regulates the endocrine function of Leydig cells.

\section{The Role of LXRs in Post-Testicular Development Events in the Epididymis}

Although LXRs have an important role in maintaining epididymal function, the 'infertility' phenotype of the $L x r \alpha \beta-/$ - mice is a composite of sequelae from testicular and epididymal dysfunction. While LXR $\beta$ is expressed throughout the epididymis, $L X R \alpha$ is expressed in only some regions of the epididymis [80]. Unlike in the testis, there are no studies exploring LXR signalling in human epididymis; however, rodent studies suggest that defective LXR signalling leads to an imbalance in cholesterol metabolism, alterations in proliferation/apoptosis, and production of proinflammatory mediators in the epididymis [81-83].

Loss of LXRs affects normal functioning of the epididymal epithelial cells required for crucial lipid modifications to spermatozoa membranes during epididymal transit. The epithelial epididymal cells in $L x r \alpha \beta$-/- mice are shrunken, with cholesteryl ester accumulation, an enlarged lumen of epididymal tubules (particularly the first 2 epididymal segments) with the presence of an amorphous substance and features similar to atherosclerosis [81].

The epididymis acts as a quality control organ, removing abnormal sperm as they transit, but when epididymal epithelial cells are dysfunctional, sperm is also affected. There is increased midpiece fragility observed in $L x r \alpha \beta-/-$ mice and the presence of isolated sperm heads and flagella [81]. Recent studies show that the epididymis from $L x r \beta$-/- mice had significantly lower levels of Srebf1, Fasn, Abca1 (likely resulting in the aforementioned cholesteryl ester deposition), Abcg1 and Idol expression [81-83]. In addition, lower sperm counts and more broken sperm tails were seen in these mice [81-83].

Recently, studies challenging 4-month-old $\operatorname{Lx} \alpha \beta$-/- mice with a high cholesterol diet (HCD) revealed accelerated changes in cholesterol deposition within the epididymis [84] with lipid deposition in the smooth muscle cells (SMCs) surrounding the epididymal tubules $[70,83]$. Epididymal SMCs in the $\operatorname{Lxr} \alpha \beta$-/- mice transdifferentiate into macrophage-like foam cells by 9 months of age or at 4 months if fed a HCD [70,83], similar to the situation seen in atherosclerosis [85]. Characterisation of 
sperm lipids from the $L x r \alpha \beta-/-H C D$ challenged mice revealed problems with sperm, with higher cholesterol:phospholipid ratios, and subsequent negative effects on the capacitation and fertilisation potential [84].

\section{LXR Loss Is Also Associated with a Pro-Inflammatory State Potentially Affecting Fertility}

Chronic testicular inflammation may result from a variety of causes which include infection, toxic insults, metabolic diseases and obesity, all of which are associated with enhanced production of proinflammatory cytokines and reactive oxygen species (ROS). This causes oxidative stress affecting male fertility [86-88]; ROS production is associated with increased germ cell apoptosis, DNA fragmentation and altered fluidity of the sperm membrane [89]. Measuring oxidative stress (OS) when assessing male infertility is one of the more recent clinical recommendations [90]. Oxidative stress is also associated with high levels of interleukin-6 (IL-6), a proinflammatory cytokine associated with unfavourable semen parameters [91].

LXRs exert anti-inflammatory effects, both direct and indirect, through transactivation or trans-repression mechanisms [5,6]. LXRs negatively regulate the expression of NF-kB dependent proinflammatory cytokines such as IL-6 [92], while SUMOylated LXR can tether corepressors to promotor sites of genes important in inflammatory responses, thus exerting anti-inflammatory effects [5,93]. LXRs also modulate Toll-like receptor 4 (TLR4) signalling, and LXR activation causes ABCA1-mediated changes in membrane lipids, disrupting the MydD88 and TRAF6 recruitment required for NF-kB signalling, therefore inhibiting production of proinflammatory cytokines [5,93].

Another potential role for LXRs in immunomodulation in the testis may occur in testicular macrophages, which are rarely studied and help to maintain testicular immune privilege. LXR-dependent processes in macrophages may mediate some of the anti-inflammatory effects in the testis, and IL-5-mediated reprogramming of macrophages is one of the immunomodulatory roles of LXRs [94,95]. Additionally, LXRs may reduce NF-kB signalling and reduce levels of the proinflammatory cytokines IL-6 and TNF $\alpha$ [96]. Support for this comes from studies of the epididymis from $L x r \alpha-/$ - and $\operatorname{Lxr} \beta-/-$ mice. These mice have increased epididymal inflammation and altered epithelial cell function; $L x r \alpha-/$ - mice have increased expression of Il-1 $\beta$ and Tnf $\alpha$ whilst $L x r \beta-/-$ mice have increased expression of $I l-6$ and Tnf $\alpha$ genes, which are associated with inflammation.

\section{Conclusions}

LXRs typically upregulate a suite of genes crucial for cholesterol balance and phospholipid remodelling with anti-inflammatory effects. In the testis and epididymis, strict lipid homeostasis is required for normal fertility: conditions associated with lipid disorders such as obesity, hypercholesterolaemia are increasingly recognised as being associated with male subfertility. Extensive rodent studies to date reveal that LXRs are crucial for male fertility, and $\operatorname{Lxr} \alpha \beta-/-$ mice become prematurely infertile due to combined problems in the testis and the epididymis. More data are required to explore the roles of LXRs in the human testis, in particular, interrogation of differences in fertility phenotypes.

Funding: We would like to thank our funders, Wellcome Trust Grant number 102758/Z/13/Z and Genesis Research Trust Gen 89, who support this work.

Conflicts of Interest: The authors declare no conflict of interest.

\section{References}

1. Chawla, A.; Repa, J.J.; Evans, R.M.; Mangelsdorf, D.J. Nuclear receptors and lipid physiology: Opening the X-files. Science 2001, 294, 1866-1870. [CrossRef] [PubMed]

2. Willy, P.J.; Umesono, K.; Ong, E.S.; Evans, R.M.; Heyman, R.A.; Mangelsdorf, D.J. LXR, a nuclear receptor that defines a distinct retinoid response pathway. Genes Dev. 1995, 9, 1033-1045. [CrossRef] [PubMed] 
3. Janowski, B.A.; Willy, P.J.; Devi, T.R.; Falck, J.R.; Mangelsdorf, D.J. An oxysterol signalling pathway mediated by the nuclear receptor LXR alpha. Nature 1996, 383, 728-731. [CrossRef] [PubMed]

4. Evans, R.M.; Mangelsdorf, D.J. Nuclear receptors, RXR, and the big bang. Cell 2014, 157, 255-266. [CrossRef]

5. Fessler, M.B. The challenges and promise of targeting the Liver X Receptors for treatment of inflammatory disease. Pharmacol. Ther. 2018, 181, 1-12. [CrossRef]

6. Maqdasy, S.; Trousson, A.; Tauveron, I.; Volle, D.H.; Baron, S.; Lobaccaro, J.-M.A. Once and for all, LXR $\alpha$ and LXR $\beta$ are gatekeepers of the endocrine system. Mol. Aspects Med. 2016, 49, 31-46. [CrossRef]

7. Chen, J.D.; Evans, R.M. A transcriptional co-repressor that interacts with nuclear hormone receptors. Nature 1995, 377, 454-457. [CrossRef]

8. Hörlein, A.J.; Näär, A.M.; Heinzel, T.; Torchia, J.; Gloss, B.; Kurokawa, R.; Ryan, A.; Kamei, Y.; Söderström, M.; Glass, C.K.; et al. Ligand-independent repression by the thyroid hormone receptor mediated by a nuclear receptor co-repressor. Nature 1995, 377, 397-404. [CrossRef]

9. Bennett, D.J.; Carswell, E.L.; Cooke, A.J.; Edwards, A.S.; Nimz, O. Design, structure activity relationships and X-Ray co-crystallography of non-steroidal LXR agonists. Curr. Med. Chem. 2008, 15, 195-209.

10. Svensson, S.; Ostberg, T.; Jacobsson, M.; Norström, C.; Stefansson, K.; Hallén, D.; Johansson, I.C.; Zachrisson, K.; Ogg, D.; Jendeberg, L. Crystal structure of the heterodimeric complex of LXRalpha and RXRbeta ligand-binding domains in a fully agonistic conformation. EMBO J. 2003, 22, 4625-4633. [CrossRef]

11. Färnegårdh, M.; Bonn, T.; Sun, S.; Ljunggren, J.; Ahola, H.; Wilhelmsson, A.; Gustafsson, J.A.; Carlquist, M. The three-dimensional structure of the liver $\mathrm{X}$ receptor beta reveals a flexible ligand-binding pocket that can accommodate fundamentally different ligands. J. Biol. Chem. 2003, 278, 38821-38828. [CrossRef] [PubMed]

12. Pehkonen, P.; Welter-Stahl, L.; Diwo, J.; Ryynänen, J.; Wienecke-Baldacchino, A.; Heikkinen, S.; Treuter, E.; Steffensen, K.R.; Carlberg, C. Genome-wide landscape of liver X receptor chromatin binding and gene regulation in human macrophages. BMC Genom. 2012, 13, 50. [CrossRef] [PubMed]

13. Boergesen, M.; Pedersen, T.Å.; Gross, B.; van Heeringen, S.J.; Hagenbeek, D.; Bindesbøll, C.; Caron, S.; Lalloyer, F.; Steffensen, K.R.; Nebb, H.I.; et al. Genome-wide profiling of liver X receptor, retinoid X receptor, and peroxisome proliferator-activated receptor $\alpha$ in mouse liver reveals extensive sharing of binding sites. Mol. Cell. Biol. 2012, 32, 852-867. [CrossRef] [PubMed]

14. de la Rosa, J.V.; Ramón-Vázquez, A.; Tabraue, C.; Castrillo, A. Analysis of LXR Nuclear Receptor Cistrome Through ChIP-Seq Data Bioinformatics. Methods Mol. Biol. 2019, 1951, 99-109. [PubMed]

15. Jakobsson, T.; Treuter, E.; Gustafsson, J.-Å.; Steffensen, K.R. Liver X receptor biology and pharmacology: New pathways, challenges and opportunities. Trends Pharmacol. Sci. 2012, 33, 394-404. [CrossRef]

16. Song, C.; Hiipakka, R.A.; Kokontis, J.M.; Liao, S. Ubiquitous receptor: Structures, immunocytochemical localization, and modulation of gene activation by receptors for retinoic acids and thyroid hormones. Ann. N. Y. Acad. Sci. 1995, 761, 38-49. [CrossRef]

17. Steffensen, K.R.; Neo, S.Y.; Stulnig, T.M.; Vega, V.B.; Rahman, S.S.; Schuster, G.U.; Gustafsson, J.A.; Liu, E.T. Genome-wide expression profiling; a panel of mouse tissues discloses novel biological functions of liver $\mathrm{X}$ receptors in adrenals. J. Mol. Endocrinol. 2004, 33, 609-622. [CrossRef]

18. Volle, D.H.; Mouzat, K.; Duggavathi, R.; Siddeek, B.; Déchelotte, P.; Sion, B.; Veyssière, G.; Benahmed, M.; Lobaccaro, J.M. Multiple roles of the nuclear receptors for oxysterols liver X receptor to maintain male fertility. Mol. Endocrinol. 2007, 21, 1014-1027. [CrossRef]

19. Wójcicka, G.; Jamroz-Wiśniewska, A.; Horoszewicz, K.; Bełtowski, J. Liver X receptors (LXRs). Part I: Structure, function, regulation of activity, and role in lipid metabolism. Postepy Hig. Med. Dosw. (Online) 2007, 61, 736-759.

20. Komati, R.; Spadoni, D.; Zheng, S.; Sridhar, J.; Riley, K.E.; Wang, G. Ligands of therapeutic utility for the liver $\mathrm{X}$ receptors. Molecules 2017, 22, 88. [CrossRef]

21. Mutemberezi, V.; Guillemot-Legris, O.; Muccioli, G.G. Oxysterols: From cholesterol metabolites to key mediators. Prog. Lipid Res. 2016, 64, 152-169. [CrossRef] [PubMed]

22. Fakheri, R.J.; Javitt, N.B. 27-Hydroxycholesterol, does it exist? On the nomenclature and stereochemistry of 26-hydroxylated sterols. Steroids 2012, 77, 575-577. [CrossRef] [PubMed]

23. Schroepfer, G.J. Oxysterols: Modulators of cholesterol metabolism and other processes. Physiol. Rev. 2000, 80, 361-554. [CrossRef] [PubMed]

24. Lobaccaro, J.M.A.; Gallot, D.; Lumbroso, S.; Mouzat, K. Liver X Receptors and female reproduction: When cholesterol meets fertility! J. Endocrinol. Investig. 2013, 36, 55-60. 
25. Zerbinati, C.; Caponecchia, L.; Puca, R.; Ciacciarelli, M.; Salacone, P.; Sebastianelli, A.; Pastore, A.; Palleschi, G.; Petrozza, V.; Porta, N.; et al. Mass spectrometry profiling of oxysterols in human sperm identifies 25-hydroxycholesterol as a marker of sperm function. Redox Biol. 2017, 11, 111-117. [CrossRef]

26. Olkkonen, V.M.; Béaslas, O.; Nissilä, E. Oxysterols and their cellular effectors. Biomolecules 2012, 2, 76-103. [CrossRef]

27. Grøndahl, C.; Ottesen, J.L.; Lessl, M.; Faarup, P.; Murray, A.; Grønvald, F.C.; Hegele-Hartung, C.; Ahnfelt-Rønne, I. Meiosis-activating sterol promotes resumption of meiosis in mouse oocytes cultured in vitro in contrast to related oxysterols. Biol. Reprod. 1998, 58, 1297-1302. [CrossRef]

28. Steffensen, K.R.; Robertson, K.; Gustafsson, J.-A.; Andersen, C.Y. Reduced fertility and inability of oocytes to resume meiosis in mice deficient of the Lxr genes. Mol. Cell. Endocrinol. 2006, 256, 9-16. [CrossRef]

29. Marín Bivens, C.L.; Lindenthal, B.; O’Brien, M.J.; Wigglesworth, K.; Blume, T.; Grøndahl, C.; Eppig, J.J. A synthetic analogue of meiosis-activating sterol (FF-MAS) is a potent agonist promoting meiotic maturation and preimplantation development of mouse oocytes maturing in vitro. Hum. Reprod. 2004, 19, 2340-2344. [CrossRef]

30. Faerge, I.; Grøndahl, C.; Ottesen, J.L.; Hyttel, P. Autoradiographic localization of specific binding of meiosis-activating sterol to cumulus-oocyte complexes from marmoset, cow, and mouse. Biol. Reprod. 2001, 64, 527-536. [CrossRef]

31. Dallel, S.; Tauveron, I.; Brugnon, F.; Baron, S.; Lobaccaro, J.M.A.; Maqdasy, S. Liver X Receptors: A Possible Link between Lipid Disorders and Female Infertility. Int. J. Mol. Sci. 2018, 19, 2177. [CrossRef] [PubMed]

32. Byskov, A.G.; Andersen, C.Y.; Nordholm, L.; Thøgersen, H.; Xia, G.; Wassmann, O.; Andersen, J.V.; Guddal, E.; Roed, T. Chemical structure of sterols that activate oocyte meiosis. Nature 1995, 374, 559-562. [CrossRef] [PubMed]

33. Fon Tacer, K.; Kalanj-Bognar, S.; Waterman, M.R.; Rozman, D. Lanosterol metabolism and sterol regulatory element binding protein (SREBP) expression in male germ cell maturation. J. Steroid Biochem. Mol. Biol. 2003, 85, 429-438. [CrossRef]

34. Keber, R.; Rozman, D.; Horvat, S. Sterols in spermatogenesis and sperm maturation. J. Lipid Res. 2013, 54, 20-33. [CrossRef]

35. Lukyanenko, Y.O.; Chen, J.J.; Hutson, J.C. Production of 25-hydroxycholesterol by testicular macrophages and its effects on Leydig cells. Biol. Reprod. 2001, 64, 790-796. [CrossRef]

36. Chen, J.-J.; Lukyanenko, Y.; Hutson, J.C. 25-hydroxycholesterol is produced by testicular macrophages during the early postnatal period and influences differentiation of Leydig cells in vitro. Biol. Reprod. 2002, 66, 1336-1341. [CrossRef]

37. Akpovi, C.D.; Yoon, S.R.; Vitale, M.L.; Pelletier, R.-M. The predominance of one of the SR-BI isoforms is associated with increased esterified cholesterol levels not apoptosis in mink testis. J. Lipid Res. 2006, 47, 2233-2247. [CrossRef]

38. Sèdes, L.; Thirouard, L.; Maqdasy, S.; Garcia, M.; Caira, F.; Lobaccaro, J.A.; Beaudoin, C.; Volle, D.H. Cholesterol: A gatekeeper of male fertility? Front. Endocrinol. (Lausanne) 2018, 9, 369. [CrossRef]

39. Wang, B.; Tontonoz, P. Liver X receptors in lipid signalling and membrane homeostasis. Nat. Rev. Endocrinol. 2018, 14, 452-463. [CrossRef]

40. Peet, D.J.; Turley, S.D.; Ma, W.; Janowski, B.A.; Lobaccaro, J.M.; Hammer, R.E.; Mangelsdorf, D.J. Cholesterol and bile acid metabolism are impaired in mice lacking the nuclear oxysterol receptor LXR alpha. Cell 1998, 93, 693-704. [CrossRef]

41. Yu, L.; York, J.; von Bergmann, K.; Lutjohann, D.; Cohen, J.C.; Hobbs, H.H. Stimulation of cholesterol excretion by the liver $\mathrm{X}$ receptor agonist requires ATP-binding cassette transporters G5 and G8. J. Biol. Chem. 2003, 278, 15565-15570. [CrossRef] [PubMed]

42. Venkateswaran, A.; Laffitte, B.A.; Joseph, S.B.; Mak, P.A.; Wilpitz, D.C.; Edwards, P.A.; Tontonoz, P. Control of cellular cholesterol efflux by the nuclear oxysterol receptor LXR alpha. Proc. Natl. Acad. Sci. USA 2000, 97, 12097-12102. [CrossRef] [PubMed]

43. Kennedy, M.A.; Barrera, G.C.; Nakamura, K.; Baldán, A.; Tarr, P.; Fishbein, M.C.; Frank, J.; Francone, O.L.; Edwards, P.A. ABCG1 has a critical role in mediating cholesterol efflux to HDL and preventing cellular lipid accumulation. Cell Metab. 2005, 1, 121-131. [CrossRef] [PubMed] 
44. Vedhachalam, C.; Duong, P.T.; Nickel, M.; Nguyen, D.; Dhanasekaran, P.; Saito, H.; Rothblat, G.H.; Lund-Katz, S.; Phillips, M.C. Mechanism of ATP-binding cassette transporter A1-mediated cellular lipid efflux to apolipoprotein A-I and formation of high density lipoprotein particles. J. Biol. Chem. 2007, 282, 25123-25130. [CrossRef] [PubMed]

45. Phillips, M.C. Molecular mechanisms of cellular cholesterol efflux. J. Biol. Chem. 2014, 289, 24020-24029. [CrossRef] [PubMed]

46. Cha, J.-Y.; Repa, J.J. The liver X receptor (LXR) and hepatic lipogenesis. The carbohydrate-response element-binding protein is a target gene of LXR. J. Biol. Chem. 2007, 282, 743-751. [CrossRef] [PubMed]

47. Demeure, O.; Lecerf, F.; Duby, C.; Desert, C.; Ducheix, S.; Guillou, H.; Lagarrigue, S. Regulation of LPCAT3 by LXR. Gene 2011, 470, 7-11. [CrossRef]

48. Ishibashi, M.; Varin, A.; Filomenko, R.; Lopez, T.; Athias, A.; Gambert, P.; Blache, D.; Thomas, C.; Gautier, T.; Lagrost, L.; et al. Liver $x$ receptor regulates arachidonic acid distribution and eicosanoid release in human macrophages: A key role for lysophosphatidylcholine acyltransferase 3. Arterioscler. Thromb. Vasc. Biol. 2013, 33, 1171-1179. [CrossRef]

49. Cao, G.; Beyer, T.P.; Yang, X.P.; Schmidt, R.J.; Zhang, Y.; Bensch, W.R.; Kauffman, R.F.; Gao, H.; Ryan, T.P.; Liang, Y.; et al. Phospholipid transfer protein is regulated by liver $\mathrm{X}$ receptors in vivo. J. Biol. Chem. 2002, 277, 39561-39565. [CrossRef]

50. Laffitte, B.A.; Joseph, S.B.; Chen, M.; Castrillo, A.; Repa, J.; Wilpitz, D.; Mangelsdorf, D.; Tontonoz, P. The phospholipid transfer protein gene is a liver $\mathrm{X}$ receptor target expressed by macrophages in atherosclerotic lesions. Mol. Cell. Biol. 2003, 23, 2182-2191. [CrossRef]

51. Okazaki, H.; Goldstein, J.L.; Brown, M.S.; Liang, G. LXR-SREBP-1c-phospholipid transfer protein axis controls very low density lipoprotein (VLDL) particle size. J. Biol. Chem. 2010, 285, 6801-6810. [CrossRef] [PubMed]

52. Alberti, S.; Schuster, G.; Parini, P.; Feltkamp, D.; Diczfalusy, U.; Rudling, M.; Angelin, B.; Björkhem, I.; Pettersson, S.; Gustafsson, J.A. Hepatic cholesterol metabolism and resistance to dietary cholesterol in LXRbeta-deficient mice. J. Clin. Investig. 2001, 107, 565-573. [CrossRef] [PubMed]

53. Zhang, Y.; Breevoort, S.R.; Angdisen, J.; Fu, M.; Schmidt, D.R.; Holmstrom, S.R.; Kliewer, S.A.; Mangelsdorf, D.J.; Schulman, I.G. Liver LXR $\alpha$ expression is crucial for whole body cholesterol homeostasis and reverse cholesterol transport in mice. J. Clin. Investig. 2012, 122, 1688-1699. [CrossRef] [PubMed]

54. de Kretser, D.M.; Loveland, K.L.; Meinhardt, A.; Simorangkir, D.; Wreford, N. Spermatogenesis. Hum. Reprod. 1998, 13 (Suppl. 1), 1-8. [CrossRef]

55. Rebourcet, D.; Darbey, A.; Monteiro, A.; Soffientini, U.; Tsai, Y.T.; Handel, I.; Pitetti, J.L.; Nef, S.; Smith, L.B.; O'Shaughnessy, P.J. Sertoli cell number defines and predicts germ and leydig cell population sizes in the adult mouse testis. Endocrinology 2017, 158, 2955-2969. [CrossRef]

56. Whitmore, L.S.; Ye, P. Dissecting Germ Cell Metabolism through Network Modeling. PLoS ONE 2015, 10, e0137607. [CrossRef]

57. Amaral, A.; Castillo, J.; Estanyol, J.M.; Ballescà, J.L.; Ramalho-Santos, J.; Oliva, R. Human sperm tail proteome suggests new endogenous metabolic pathways. Mol. Cell Proteom. 2013, 12, 330-342. [CrossRef]

58. Shi, J.-F.; Li, Y.-K.; Ren, K.; Xie, Y.-J.; Yin, W.-D.; Mo, Z.-C. Characterization of cholesterol metabolism in Sertoli cells and spermatogenesis (Review). Mol. Med. Rep. 2018, 17, 705-713. [CrossRef]

59. Potter, J.E.; Millette, C.F.; James, M.J.; Kandutsch, A.A. Elevated cholesterol and dolichol synthesis in mouse pachytene spermatocytes. J. Biol. Chem. 1981, 256, 7150-7154.

60. Lenzi, A.; Picardo, M.; Gandini, L.; Dondero, F. Lipids of the sperm plasma membrane: From polyunsaturated fatty acids considered as markers of sperm function to possible scavenger therapy. Hum. Reprod. Update 1996, 2, 246-256. [CrossRef]

61. Ladha, S. Lipid heterogeneity and membrane fluidity in a highly polarized cell, the mammalian spermatozoon. J. Membr. Biol. 1998, 165, 1-10. [CrossRef] [PubMed]

62. Rebourcet, D.; O'Shaughnessy, P.J.; Pitetti, J.-L.; Monteiro, A.; O’Hara, L.; Milne, L.; Tsai, Y.T.; Cruickshanks, L.; Riethmacher, D.; Guillou, F.; et al. Sertoli cells control peritubular myoid cell fate and support adult Leydig cell development in the prepubertal testis. Development 2014, 141, 2139-2149. [CrossRef] [PubMed]

63. Shen, W.-J.; Azhar, S.; Kraemer, F.B. SR-B1: A Unique Multifunctional Receptor for Cholesterol Influx and Efflux. Annu. Rev. Physiol. 2018, 80, 95-116. [CrossRef] [PubMed] 
64. Wagner, B.L.; Valledor, A.F.; Shao, G.; Daige, C.L.; Bischoff, E.D.; Petrowski, M.; Jepsen, K.; Baek, S.H.; Heyman, R.A.; Rosenfeld, M.G.; et al. Promoter-specific roles for liver X receptor/corepressor complexes in the regulation of ABCA1 and SREBP1 gene expression. Mol. Cell. Biol. 2003, 23, 5780-5789. [CrossRef]

65. Fan, Y.; Liu, Y.; Xue, K.; Gu, G.; Fan, W.; Xu, Y.; Ding, Z. Diet-induced obesity in male C57BL/6 mice decreases fertility as a consequence of disrupted blood-testis barrier. PLoS ONE. 2015, 10, e0120775. [CrossRef]

66. Maqdasy, S.; El Hajjaji, F.-Z.; Baptissart, M.; Viennois, E.; Oumeddour, A.; Brugnon, F.; Trousson, A.; Tauveron, I.; Volle, D.; Lobaccaro, J.M.; et al. Identification of the Functions of Liver X Receptor- $\beta$ in Sertoli Cells Using a Targeted Expression-Rescue Model. Endocrinology 2015, 156, 4545-4557. [CrossRef]

67. Miller, W.L.; Bose, H.S. Early steps in steroidogenesis: Intracellular cholesterol trafficking. J. Lipid Res. 2011, 52, 2111-2135. [CrossRef]

68. El-Hajjaji, F.-Z.; Oumeddour, A.; Pommier, A.J.C.; Ouvrier, A.; Viennois, E.; Dufour, J.; Caira, F.; Drevet, J.R.; Volle, D.H.; Baron, S.; et al. Liver X receptors, lipids and their reproductive secrets in the male. Biochim. Biophys. Acta 2011, 1812, 974-981. [CrossRef]

69. Ramírez-Torres, M.A.; Carrera, A.; Zambrana, M. [High incidence of hyperestrogenemia and dyslipidemia in a group of infertile men]. Ginecol. Obstet. Mex. 2000, 68, 224-229.

70. Ouvrier, A.; Alves, G.; Damon-Soubeyrand, C.; Marceau, G.; Cadet, R.; Janny, L.; Brugnon, F.; Kocer, A.; Pommier, A.; Lobaccaro, J.M.; et al. Dietary cholesterol-induced post-testicular infertility. PLoS ONE 2011, 6, e26966. [CrossRef]

71. de Neergaard, R.; Nielsen, J.E.; Jørgensen, A.; Toft, B.G.; Goetze, J.P.; Jørgensen, N. Positive association between cholesterol in human seminal plasma and sperm counts: Results from a cross-sectional cohort study and immunohistochemical investigations. Andrology 2018, 6, 817-828. [CrossRef] [PubMed]

72. Liu, C.Y.; Chou, Y.C.; Lin, S.H.; Wu, S.T.; Cha, T.L.; Chen, H.I.; Tsao, C.W. Serum lipid profiles are associated with semen quality. Asian J. Androl. 2017, 19, 633-638. [PubMed]

73. Robertson, K.M.; Schuster, G.U.; Steffensen, K.R.; Hovatta, O.; Meaney, S.; Hultenby, K.; Johansson, L.C.; Svechnikov, K.; Söder, O.; Gustafsson, J.A. The liver X receptor-\{beta\} is essential for maintaining cholesterol homeostasis in the testis. Endocrinology 2005, 146, 2519-2530. [CrossRef] [PubMed]

74. Rondanino, C.; Ouchchane, L.; Chauffour, C.; Marceau, G.; Déchelotte, P.; Sion, B.; Pons-Rejraji, H.; Janny, L.; Volle, D.H.; Lobaccaro, J.M.; et al. Levels of liver X receptors in testicular biopsies of patients with azoospermia. Fertil. Steril. 2014, 102, 361-371. [CrossRef]

75. Massin, N.; Bry, H.; Vija, L.; Maione, L.; Constancis, E.; Haddad, B.; Morel, Y.; Claessens, F.; Young, J. Healthy birth after testicular extraction of sperm and ICSI from an azoospermic man with mild androgen insensitivity syndrome caused by an androgen receptor partial loss-of-function mutation. Clin. Endocrinol. (Oxf.). 2012, 77, 593-598. [CrossRef]

76. Smith, L.B.; Walker, W.H. The regulation of spermatogenesis by androgens. Semin. Cell Dev. Biol. 2014, 30, 2-13. [CrossRef]

77. O'Shaughnessy, P.J.; Monteiro, A.; Verhoeven, G.; De Gendt, K.; Abel, M.H. Effect of FSH on testicular morphology and spermatogenesis in gonadotrophin-deficient hypogonadal mice lacking androgen receptors. Reproduction 2010, 139, 177-184. [CrossRef]

78. Kruse, M.S.; Suarez, L.G.; Coirini, H. Regulation of the expression of LXR in rat hypothalamic and hippocampal explants. Neurosci. Lett. 2017, 639, 53-58. [CrossRef]

79. Kruse, M.S.; Suarez, L.G.; Coirini, H. LXR activation increases the expression of GnRH AND $\alpha \mathrm{MSH}$ in the rat hypothalamus in vivo. Neurosci. Lett. 2018, 664, 20-27. [CrossRef]

80. Frenoux, J.M.; Vernet, P.; Volle, D.H.; Britan, A.; Saez, F.; Kocer, A.; Henry-Berger, J.; Mangelsdorf, D.J.; Lobaccaro, J.M.; Drevet, J.R. Nuclear oxysterol receptors, LXRs, are involved in the maintenance of mouse caput epididymidis structure and functions. J. Mol. Endocrinol. 2004, 33, 361-375. [CrossRef]

81. Saez, F.; Chabory, E.; Cadet, R.; Vernet, P.; Baron, S.; Lobaccaro, J.M.; Drevet, J.R. Liver X receptors and epididymal epithelium physiology. Asian J. Androl. 2007, 9, 574-582. [CrossRef] [PubMed]

82. Ouvrier, A.; Cadet, R.; Vernet, P.; Laillet, B.; Chardigny, J.M.; Lobaccaro, J.M.; Drevet, J.R.; Saez, F. LXR and ABCA1 control cholesterol homeostasis in the proximal mouse epididymis in a cell-specific manner. J. Lipid Res. 2009, 50, 1766-1775. [CrossRef] [PubMed]

83. Whitfield, M.; Ouvrier, A.; Cadet, R.; Damon-Soubeyrand, C.; Guiton, R.; Janny, L.; Kocer, A.; Marceau, G.; Pons-Rejraji, H.; Trousson, A.; et al. Liver X receptors (lxrs) alpha and beta play distinct roles in the mouse epididymis. Biol. Reprod. 2016, 94, 55. [CrossRef] [PubMed] 
84. Whitfield, M.; Guiton, R.; Rispal, J.; Acar, N.; Kocer, A.; Drevet, J.R.; Saez, F. Dyslipidemia alters sperm maturation and capacitation in LXR-null mice. Reproduction 2017, 154, 827-842. [CrossRef] [PubMed]

85. Rong, J.X.; Shapiro, M.; Trogan, E.; Fisher, E.A. Transdifferentiation of mouse aortic smooth muscle cells to a macrophage-like state after cholesterol loading. Proc. Natl. Acad. Sci. USA 2003, 100, 13531-13536. [CrossRef] [PubMed]

86. Bachir, B.G.; Jarvi, K. Infectious, inflammatory, and immunologic conditions resulting in male infertility. Urol. Clin. N. Am. 2014, 41, 67-81. [CrossRef]

87. Ko, E.Y.; Sabanegh, E.S.; Agarwal, A. Male infertility testing: Reactive oxygen species and antioxidant capacity. Fertil. Steril. 2014, 102, 1518-1527. [CrossRef]

88. Agarwal, A.; Rana, M.; Qiu, E.; AlBunni, H.; Bui, A.D.; Henkel, R. Role of oxidative stress, infection and inflammation in male infertility. Andrologia 2018, 50, e13126. [CrossRef]

89. Agarwal, A.; Saleh, R.A.; Bedaiwy, M.A. Role of reactive oxygen species in the pathophysiology of human reproduction. Fertil. Steril. 2003, 79, 829-843. [CrossRef]

90. Dutta, S.; Majzoub, A.; Agarwal, A. Oxidative stress and sperm function: A systematic review on evaluation and management. Arab J. Urol. 2019, 17, 87-97. [CrossRef]

91. Nallella, K.P.; Allamaneni, S.S.R.; Pasqualotto, F.F.; Sharma, R.K.; Thomas, A.J.; Agarwal, A. Relationship of interleukin-6 with semen characteristics and oxidative stress in patients with varicocele. Urology 2004, 64, 1010-1013. [CrossRef] [PubMed]

92. Joseph, S.B.; Castrillo, A.; Laffitte, B.A.; Mangelsdorf, D.J.; Tontonoz, P. Reciprocal regulation of inflammation and lipid metabolism by liver $\mathrm{X}$ receptors. Nat. Med. 2003, 9, 213-219. [CrossRef] [PubMed]

93. Ito, A.; Hong, C.; Rong, X.; Zhu, X.; Tarling, E.J.; Hedde, P.N.; Gratton, E.; Parks, J.; Tontonoz, P. LXRs link metabolism to inflammation through Abca1-dependent regulation of membrane composition and TLR signaling. Elife 2015, 4, e08009. [CrossRef] [PubMed]

94. Chen, Y.; Duan, Y.; Yang, X.; Sun, L.; Liu, M.; Wang, Q.; Ma, X.; Zhang, W.; Li, X.; Hu, W.; et al. Inhibition of ERK1/2 and activation of LXR synergistically reduce atherosclerotic lesions in ApoE-deficient mice. Arterioscler. Thromb. Vasc. Biol. 2015, 35, 948-959. [CrossRef]

95. Chen, Y.; Duan, Y.; Kang, Y.; Yang, X.; Jiang, M.; Zhang, L.; Li, G.; Yin, Z.; Hu, W.; Dong, P.; et al. Activation of liver $X$ receptor induces macrophage interleukin-5 expression. J. Biol. Chem. 2012, 287, 43340-43350. [CrossRef]

96. Bhushan, S.; Tchatalbachev, S.; Lu, Y.; Fröhlich, S.; Fijak, M.; Vijayan, V.; Chakraborty, T.; Meinhardt, A. Differential activation of inflammatory pathways in testicular macrophages provides a rationale for their subdued inflammatory capacity. J. Immunol. 2015, 194, 5455-5464. [CrossRef] 